\title{
MICRO BIOSTRATIGRAPHY AND LITHOSTRATIGRAPHY OF THE UPPER PERMIAN DALAN FORMATION (ZAGROS BASIN, SOUTHWEST IRAN)
}

\author{
Pedram Rafiee $^{1}$--- Dariush Baghbani² --- Ali Aghanabati ${ }^{3}$--- Mehran Arian ${ }^{4}$ \\ ${ }^{1,4}$ Department of Geology, College of Basic Science, Tehran Science and Research Branch, Islamic Azad University, \\ Tehran, Iran \\ ${ }^{2}$ Department of Geology, College of Basic Sciences, Damavand Branch, Islamic Azad University, Tehran, Iran \\ ${ }^{s}$ Department of Geology, College of Basic Sciences, North Tehran Branch, Islamic Azad University, Tehran, Iran
}

\begin{abstract}
The objective of the present study is to perform Microbiostratigraphy and Lithostratigraphy of the Upper Permian Dalan Formation at a Well (Well 1) in the Zagros Basin. The Upper Permian Dalan Formation contains vast gas reservoirs in the southwest Iran and is composed of three Members: The Lower Dalan Member corresponds to Wordian to Capitanian; the Nar Member is latest Capitanian and the Upper Dalan Member corresponds to Wuchiapingian to Changhsingian. Lower and Upper Dalan Members include mainly limestone, dolomitic limestone and Nar member mostly consists of anhydrite and thin interlayer of dolomite. The biostratigraphic study allows individualizing Foraminifers from the Wordian to the Changhsingian (Middle to Late Permian). Based on the stratigraphic distributions of the Biostratigraphically significant fauna and flora the following 7 biozones and age determinations are proposed in the Upper Permian Dalan Formation:

7. Paraglobivalvulinoides septulifera zone (Changhsingian)

6. Paradagmarita zone (Changhsingian)

5. Rectostipulina zone (Wuchiapingian)

4. Shanita zone (Capitanian)

3. Paraglobivalvulina zone (Capitanian)

2. Globivalvulina zone (Wordian)

1. Eoverbeekina zone (Wordian)
\end{abstract}

Keywords: Micro biostratigraphy, Lithostratigraphy, Dalan, Permian, Zagros, Biozone, Formation, Southwest Iran. 


\section{Contribution/Originality}

The study area is important by including the gas fields in the Permian sequences of different layers. The results of this study will help to make Paleogeographic maps and interpretation of Permian Basin. Some objectives of the study are summarized as follows:

- Recognition of lithology specificities

- Separation and definitaion of the Permian sequence

- Paleontology to determine the stratigraphic range of foraminifera

- Determine the age and thickness of stratigraphic and biostratigraphic units

\section{INTRODUCTION}

Located in the middle part of the Alpine-Himalayan orogenic belt, the Zagros basin is approximately $1400 \mathrm{~km}$ long and $190 \mathrm{~km}$ wide extending NW-SE from the Taurus Mountains in NE Turkey to the Strait of Hormuz in Iran (Stocklin, 1968; Falcon, 1969; Haynes and McQuillan, 1974; Scott, 1981). The belt is bounded to the NE by the Main Zagros Thrust and to the SW by the Persian Gulf, which represents its present-day active foreland basin. The Zagros deformation front, defined by topography, is roughly parallel to the Northeastern shoreline of the Persian Gulf. The Zagros Fault Thrust Belt is divided into two tectonic zones from the NE to the SW: The Thrust zone and the Folded Zagros (Falcon, 1967; 1974; Stocklin, 1968). The Folded Zagros is subdivided according to its tectonic and sedimentary evolution into three domains: Lurestan, Dezful Embayment/Izeh zone/Abadan Plain and Fars (Motiei, 1994; 1995) (Fig.1). The study area is located in the NW part of the Fars province. This region presents a particular complexity due to the overprint of two different orogenic systems, the Late Cretaceous obduction and thrusting that affected the Northern border of the Arabian plate from Oman to Cyprus (Ricou, 1971) and the Neogene Zagros-Makran orogeny (Stocklin, 1968; Falcon, 1969; Alavi, 1974; Ricou et al., 1977).

In the Zagros Mountains during the early Permian clastic series of the Faraghan Formation were deposited; these were succeeded by shallow water fusulinid limestones and dolostones of the Middle Permian and Late Permian Dalan Formation. The dolostones and limestones of the Permian Dalan Formation contain vast gas reserves in the Zagros region. This formation is named after the Dalan anticline situated 110 kilometers S-SW of Shiraz. The formation has a total thickness of more than 630 meters. Stratigraphic cross section of Dalan Formation measured at Kuh-e-Faraghan is the thickest section of this Formation. This is overlain conformably by the carbonates Kangan Formation of Triassic age (Szabo and Kheradpir, 1978). In its type section, the Dalan Formation overlies the Faraghan Formation and embraces all the continuous carbonates and evaporites of Permian age. The presence of marine fossils particularly Fusulinidae family, indicate open marine conditions during its deposition (Ghazban and Motiei, 2007). The Dalan Formation together with the underlying Faraghan Formation and the overlying Kangan Formation, were placed in "the Deh Ram Group", a term introduced by Szabo and Kheradpir (1978). Deh Ram is a name of a place $20 \mathrm{~km}$ SSW of Surmeh Mountain $230 \mathrm{~km}$ SE of Shiraz. According to Motiei (1994), the Deh Ram Group encompasses three Formations namely 
Faraghan, Dalan and Kangan with the later Formation is assigned a Triassic age. The Deh Ram Group is the world's richest gas-bearing rocks and hosts both giant and supergiant gas fields (Ghazban and Motiei, 2007).

More than a century of geological studies and exploration of hydrocarbon reservoirs led to the discovery of huge and valuable hydrocarbon reservoirs in the Zagros. The presence of repeated and extensive source rock beds; excellent carbonate and some sandstone reservoirs in good juxtaposition; efficient regional seals; huge anticline traps; continuous sedimentation and active tectonic regimes during most of the Phanerozoic make the Zagros region as one of the richest provenances in the world in terms of hydrocarbon accumulations.

The first observations and investigations regarding the Permian and Triassic sequences were made in the Zagros basin in 1930 by (Harrison, 1930). In addition, Study of Dalan Fm. By James and Wynd (1965), Stocklin (1968), Setudehnia (1978), Szabo and Kheradpir (1978), Baghbani (1988), Beydoun (1991), Insalaco et al. (2006) can be mentioned.

Fig-1. The Study area in Zagros Basin, Southwest Iran

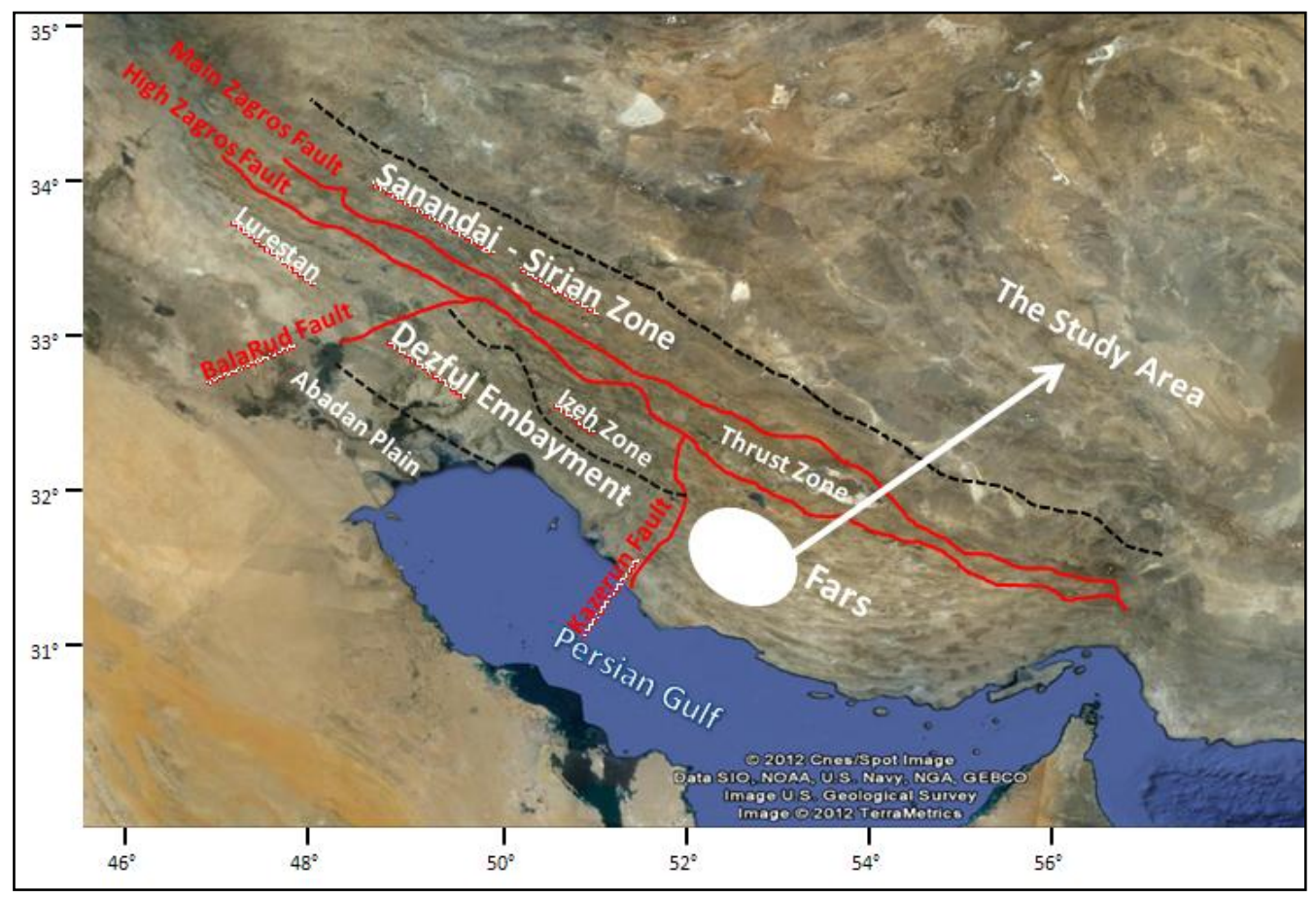

\subsection{Method of Study}

Stratigraphically, this study is focused on the Upper Permian Dalan Formation which is equivalent to the Upper Khuff in Qatar, United Arab Emirates and Saudi Arabia (Sharland et al., 2001).

Microbiostratigraphy and Lithostratigraphy of the Upper Permian Dalan Formation in the Zagros basin was carried out in several steps as follows: 
1. Collection of articles, reports and maps pertaining to previous studies conducted in the study area.

2. Microbiostratigraphy and Lithostratigraphy studies of Thin sections and Cores in Well 1 in order to identify the Permian Microfossils, Biozones and Dunham classification

3. Depict of stratigraphic column

4. Investigation and resolution of Lithostratigraphic units

5. Plotting of Microfossils ranges

6. Investigation and resolution of Biostratigraphic units and determine their age

Biostratigraphically, the results are consistent with the studies of Vachard et al. (2002), Jenny and Stampfli (2000), Kobayashi (2006) and Baghbani (1988).

\section{DISCUSSION}

\subsection{Study Location and Geological Overview}

This paper focuses on the Upper Permian Dalan Formation at a Well 1 in the Zagros basin which provides excellent analogues of Middle East Permian Sediments. The Well 1 is located at Fars zone from Zagros basin (Fig.1). Fars zone is divided into two zones: Inner Fars and Outer Fars. The Outer Fars is subdivided into Coastal Fars and Subsoastal Fars and provides continuous sequence from the base of the Lower Dalan Member to the base of the Kangan Formation; thus the entire Dalan sequence has been studied. The Zagros fold and thrust belt was formed by collision of two tectonic plates; the Iranian and Arabian Plates. Recent GPS measurements in Iran have shown that this collision is still active and the resulting deformation is distributed non-uniformly in the country, mainly taken up in the major mountain belts like Alborz and Zagros (Nilforoushan et al., 2003).

\subsection{Lithostratigraphy of Well 1 Subsurface}

Following the Permo-Carboniferous glaciations and the Pangean assembly, the Middle Permian is marked by a global drying of climate (Angiolini et al., 2003). Thus the Late Palaeozoic evolved from icehouse during the Early Permian (Cisuralian) to greenhouse period during the Late Permian-Early Triassic (Kidder and Worsley, 2004). Well 1 is placed in Fars zone from the Folded Zagros Belt (Interior Fars). In this study the Dalan Formation is about 652 m thick which overlays the clastic and shale Faraghan Formation and is Middle to Late Permian in age. Dalan Formation is divided into 3 members, respectively, Lower Dalan, Nar and Upper Dalan and from the bottom to the top (Appendix 1).

\section{- Lower Dalan Member from 11586 to 10780 F.}

The Lower Dalan Member is $247 \mathrm{~m}$ thick and is composed by fossiliferous limestones weakly dolomitised as follows and from the base to the top:

106m, White to gray limestone containing Foraminifera, Echinoderm debris, Bryozoa debris, Algae, Shell debris and Ooid inter-bedded with some minor thin layers of dark brown dolomite and white to off-white anhydrite. 
$\checkmark \quad 54 \mathrm{~m}$, Gray limestone containing Foraminifera, Echinoderm debris, Bryozoa debris, Shell debris, Stromatolite and Ooid inter-bedded with dark brown dolomite at the middle.

$\checkmark 49 \mathrm{~m}$, white limestone containing Foraminifera, Echinoderm debris, Shell debris, Stromatolite inter-bedded with dark brown dolomite at the middle.

$\checkmark \quad 25 \mathrm{~m}$, white to gray limestone containing Echinoderm debris, Shell debris and Ooid.

$\checkmark 13 \mathrm{~m}$, white to gray limestone containing Pelloid inter-bedded with white Anhydrite at the base.

\section{- Nar Member from 10780 to $10295 \mathrm{~F}$.}

The Nar Member is $154 \mathrm{~m}$ thick and is characterized by Mud-dominated deposits. This succession shows huge variations of facies association. The Nar Member consists in an evaporitic unit (hard to very hard cryptocrystalline and sucrosic anhydrite and light gray to dark brown dolomite), which could correspond to the Middle anhydrite separating the Lower and Upper Dalan Members. Generally, these facies are interpreted as deposits in semi-enclosed hyper saline depressions, in a relative sea level falling (Insalaco et al., 2006). However in Kuh-e-Gahkum and Kuh-e-Faraghan outcrops, the depositional environment corresponds to open-marine carbonates (Szabo and Kheradpir, 1978). Lithological succession of Nar Member is as follows and from the base to the top:

$\checkmark 69 \mathrm{~m}$, white to gray limestone inter-bedded with dark brown dolomite at the base and containing Foraminifera, Shell debris and Ooid.

$\checkmark 12 \mathrm{~m}$, interlayers of dark brown dolomite and white anhydrite.

$\checkmark 55 \mathrm{~m}$, gray limestone inter-bedded with white anhydrite at the base and containing Foraminifera, Shell debris and Ooid.

$\checkmark 18 \mathrm{~m}$, interlayers of white anhydrite and dark brown dolomitic limestone.

- Upper Dalan Member from 10295 to $9388 \mathrm{~F}$.

The Upper Dalan Member is $251 \mathrm{~m}$ thick and mainly is made up ooids dominated facies deposited in platform morphology which were deposited in high energy conditions and locally has been divided into 4 members as follows:

\section{○ Member 1}

$\checkmark \quad$ 92m, gray limestone containing Foraminifera, Algae, Shell debris, Ooid and Pelloid and interlayers of white limestone and dark brown dolomite at the middle.

\section{○ Member 2}

$\checkmark$ 82m, cream to white dolomitic limestone containing Foraminifera, Echinoderm debris, Algae and Shell debris.

\section{○ Member 3}

$\checkmark$ 30m, light brown limestone containing Foraminifera, Gastropod debris, Echinoderm debris, Ostracod debris, Algae and Shell debris. 
25m, gray limestone inter-bedded with white Anhydrite at the base containing Foraminifera, Gastropod debris, Echinoderm debris, Ostracod debris, Bryozoa debris, Algae and Shell debris.

\section{- Member 4}

$\checkmark \quad 22 \mathrm{~m}$, gray to dark gray limestone containing Foraminifera, Gastropod debris, Algae and Shell debris.

\subsection{Microbiostratigraphy of Well 1 Subsurface}

The main results of the Paleontological study are resumed in Appendix 1 and correspond to the biostratigraphic synthesis of the Well1. The main Foraminifera and Non-Foraminifera associations are presented and illustrated in the following plate (Plate 1). The associations are discussed in term of their occurrence and their abundance in the Well 1.

\section{- The Lower Dalan Member}

The Lower Dalan Member is Guadalupian in age (Wordian-Upper Capitanian stages) (Szabo and Kheradpir, 1978). Foraminiferal assemblage described in this area and marking this period consists in an Eoverbeekina zone. This biozone is observed in the Thrust zone and the Folded Zagros (Baghbani, 1988). For the authors the occurrence of Eoverbeekina sp. designates the Murgabian, i.e. Wordian. The Eoverbeekina zone is associated with Gymnocodium sp., Stromatolite, Echinoderm debris and Non-Skeletal grains including Ooid and Pelloid.

The Lower Dalan Member is extremely rich in macrofossils including Echinoderm debris and Bryozoa debris.

\section{- The Nar Member}

The Nar Member is uppermost Capitanian in age (Baghbani, 1988; Vachard et al., 2002; Insalaco et al., 2006). In the both Fars area and Zagros Mountains the first appearance of Globivalvulina can correspond to the Nar Member (Baghbani, 1988). In the Well 1, the Nar Member is characterized by one of the main appearance of Globivalvulina. In the Well 1, the Globivalvulina is associated with Non-Skeletal grains including Ooids.

In the Well 1, the Capitanian stage includes the Paraglobivalvulina zone which is attested by the occurrence of Paraglobivalvulina sp.. This zone consists in an assemblage of Pachyphloia sp. and Non-Skeletal grains including Ooids. As reported by (Baghbani, 1988; Insalaco et al., 2006), the latest Capitanian is attested by the first occurrence of Shanita. In the Well 1, the typical Shanita is associated with Non-Skeletal grains including Ooids.

\section{- The Upper Dalan Member}

According to Szabo and Kheradpir (1978), Baghbani (1988) and Sharland et al. (2001), this member is Lopingian in age. In the Fars area the appearance of Rectostipulina can correspond to the Upper Dalan Member (Baghbani, 1988). 
In Well 1 the Wuchiapingian stage includes the Rectostipulina zone which is attested by the occurrence of Rectostipulina sp.. This zone consists in an assemblage of Shanita sp., Hemigordiopsis sp., Nankinella sp., Earlandia sp., Stromatolite, Pachyphloia sp., Globivalvulina sp., Gymnocodium sp., Pseudovermiporella sp., Echinoderm debris and Non-Skeletal grains including Ooid and Pelloid.

In Fars area, it generally admits that the Changhsingian interval include a Paradagmarita zone (Baghbani, 1988). In Well 1, the occurrence of Paradagmarita allows us to define a Paradagmarita zone for the Upper Dalan Member which confirm the Changhsingian age. This genius is associated with Paradagmarita monody, Globivalvulina sp., Pachyphloia sp., Geinitzina sp., Staffella sp., Sphaerulina sp., Hemigordiopsis sp., large assemblage of Hemigordius sp., Mizzia sp., Echinoderm debris and Gastropod debris.

Finally, in the both Fars area and Zagros Mountains the latest Lopingian is attested by the beginning of the Paraglobivalvulinoides septulifera, and the first occurrence of Paraglobivalvulinoides septulifera (Baghbani, 1988).

In the Well 1 the latest Lopingian includes the Paraglobivalvulinoides septulifera zone which is attested by the occurrence of Paraglobivalvulinoides septulifera. This zone consists in an assemblage of Nankinella spp., Pachyphloia sp., Geinitzina sp., Hemigordius sp., Globivalvulina sp., Pachyphloia iranica, Tubiphytes, Mizzia sp., Echinoderm debris, Ostracod debris, Bryozoa debris and Gastropod debris.

\section{CONCLUSION}

In Well 1, The Upper Permian Dalan Formation contains vast gas reservoirs in the southwest Iran and is composed of 1) The Lower Dalan Member corresponds to Wordian to Capitanian; 2) the Nar Member is latest Capitanian and 3) the Upper Dalan Member corresponds to Wuchiapingian to Changhsingian. Lower and Upper Dalan Members include mainly limestone, dolomitic limestone and Nar member mostly consists of anhydrite and thin interlayer of dolomite. The biostratigraphic study allows individualizing Foraminifers from the Wordian to the Changhsingian (Middle to Late Permian). Based on the stratigraphic distributions of the Biostratigraphically significant fauna and flora 7 biozones and age determinations are proposed in the Upper Permian Dalan Formation. 
International Journal of Geography and Geology, 2014, 3(3): 45-55
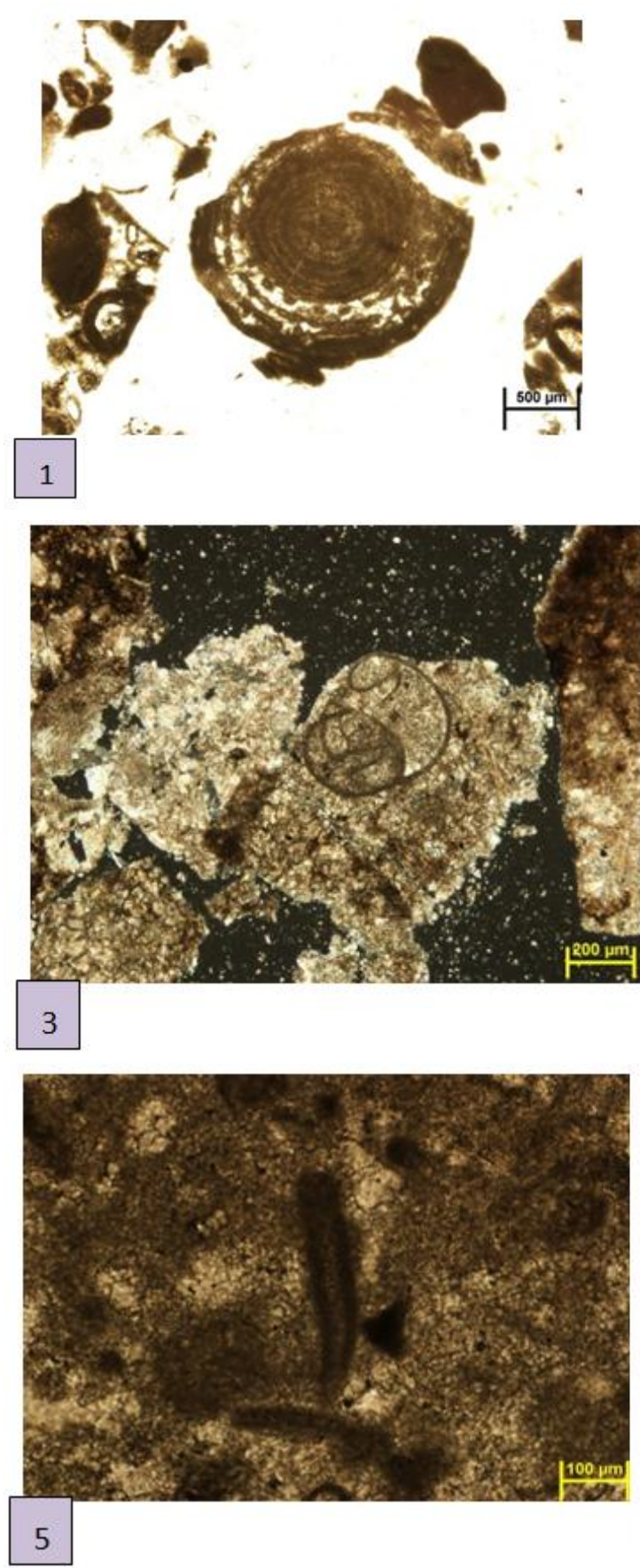
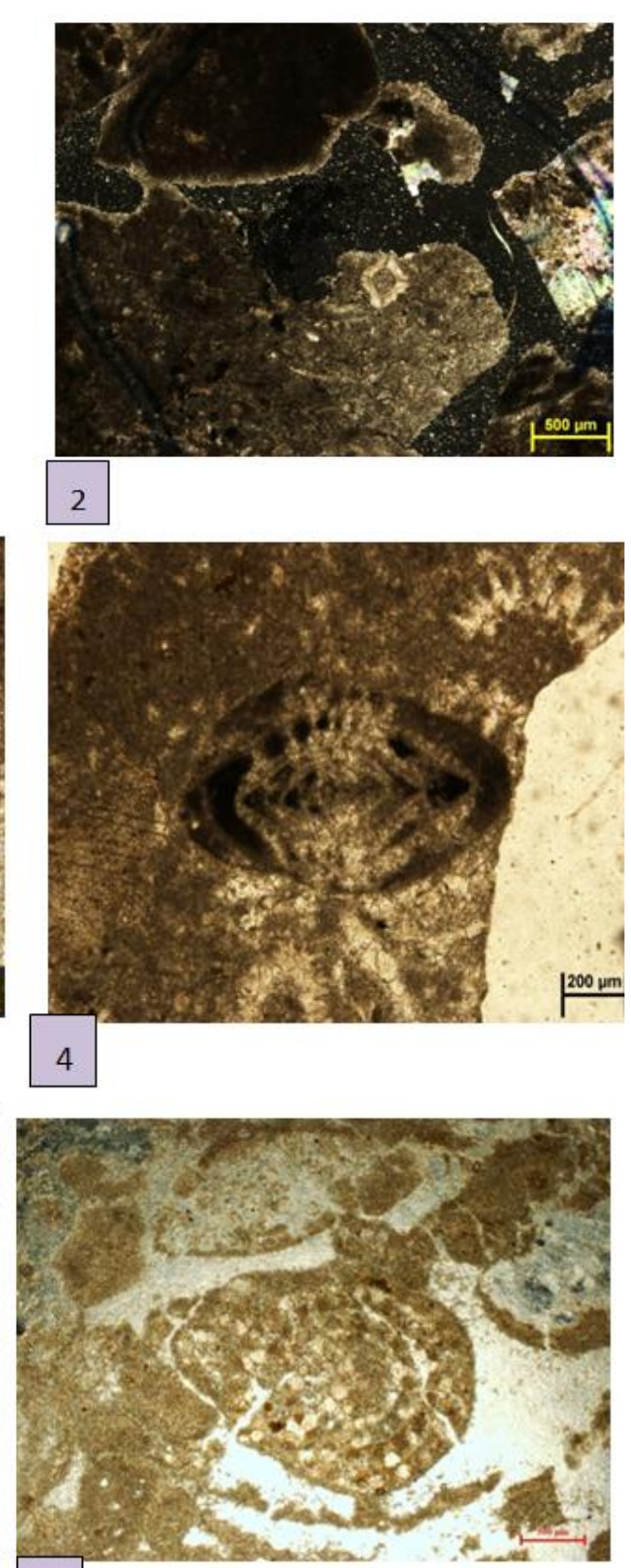

6 

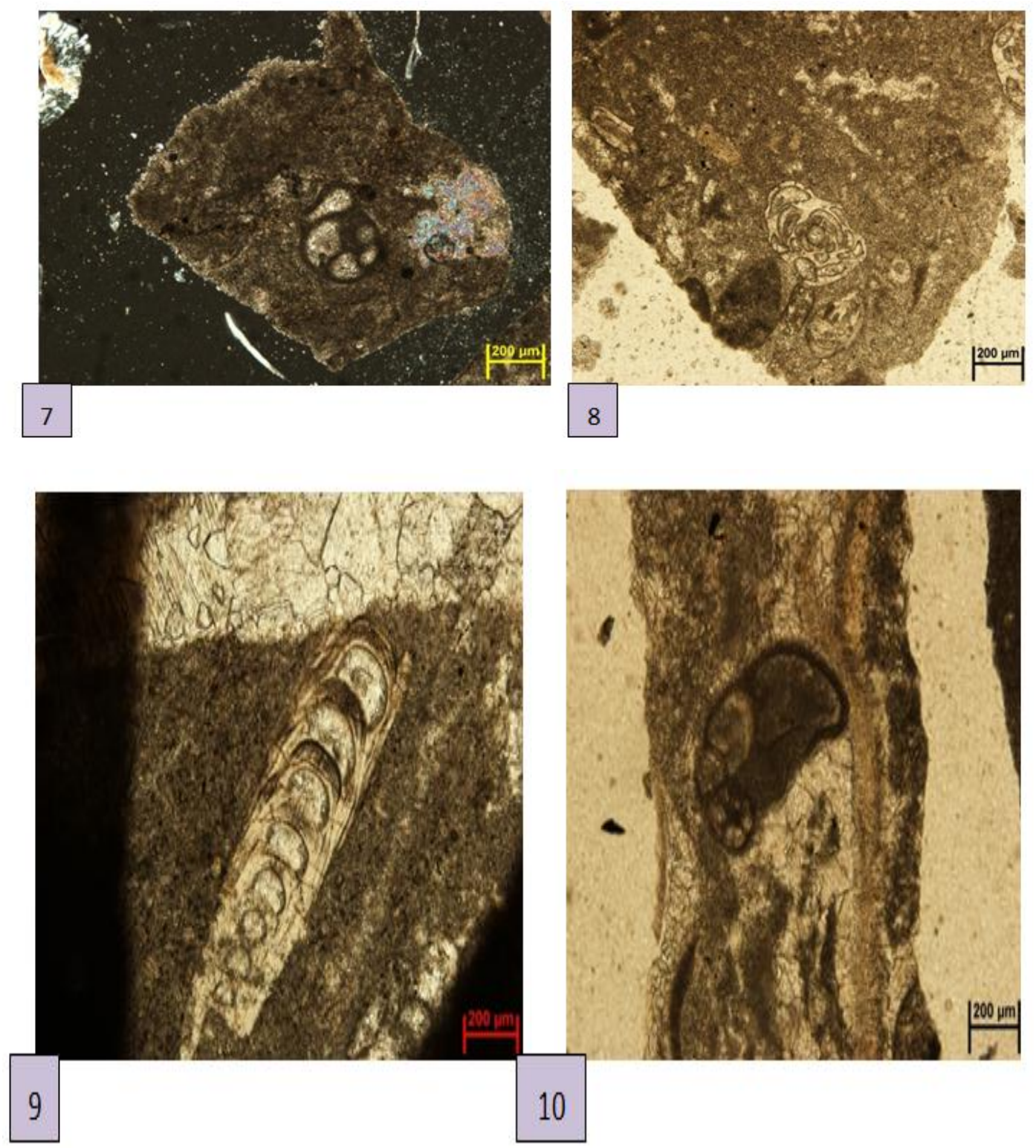

1. Shanita sp.

2. Rectostipulina sp.

3. Paraglobivalvulinoides septulifera

4. Nankinella sp.

5. Earlandia sp.

6. Eoverbeekina sp.

7. Globivalvulina sp.

8. Hemigordius sp.

9. Pachyphloia sp.

10. Paradagmarita sp. 
Funding: This study received no specific financial support.

Competing Interests: The authors declare that they have no competing interests.

Contributors/Acknowledgement: All authors contributed equally to the conception and design of the study.

\section{REFERENCES}

Alavi, M.A., 1974. Tectonics of the Zagros orogenic belt of Iran; new data and interpretations. Tectonophys, 229(3-4): 211-238.

Angiolini, L., M. Balini, E. Garzanti, A. Nicora and A. Tintori, 2003. Gondwanan deglaciation and opening of Neotethys: The Al Khlata and Saiwan Formations of Interior Oman, 196(1-2): 99-123.

Baghbani, D., 1988. Shanita zone and its biostratigraphic significance in South and Southwest Iran. In: Review Paleobiology, Special, 2(Benthos 1986): 37.

Beydoun, Z.R., 1991. Arabian plate hydrocarbon geology and potential a plate tectonic approach. Am. Assoc. Petrol. Geol. Bull., 33(3): 77.

Falcon, N.L., 1967. The geology of the Northeast margin of the Arabian Basement shield. Advanc. Sci., 24(112): $31-42$.

Falcon, N.L., 1969. Problems of the relationship between surface structures and deep displacements illustrated by the Zagros range. In: Kent, P., Satterhwaite, G. E. and Spencer, A. M., (Eds), Time and place in orogeny. Geol. Soc. London: Spec. Pub. pp: 9-22.

Falcon, N.L., 1974. Southern Iran: Zagros mountains: In a. Spencer, Ed., Mesozoic-Cenozoic Orogenic Belts: Geol. Soc., London: Spec. Publ. pp: 199-211.

Ghazban, F. and H. Motiei, 2007. Petroleum geology of the Persian Gulf. Tehran University and National Iranian Oil Company. ISBN 964-03-9420-3. pp: 707.

Harrison, J.V., 1930. The geology of some salt plugs in Laristan: Quar. Jour. Geol. Soc. London, 86: 463-522.

Haynes, S.J. and H. McQuillan, 1974. Evolution of the Zagros suture zone. Southern Iran. Geol. Soc., Am. Bull., 85(5): 739-744.

Insalaco, E., A. Virgone, B. Courme, J. Gaillot, M. Kamali, A. Moallemi, M. Lotfpour and S. Mobini, 2006. Upper dalan member and kangan formation between the Zagros mountains and offshore Fars, Iran: Depositional system, biostratigraphy and stratigraphy architecture. GeoArabia, 11(2): 75176.

James, G.A. and J.G. Wynd, 1965. Stratigraphic nomenclature of Iranian oil consortium agreement area. Am. Ass. Petrol. Geol. Bull., 49(12): 2 182-2245.

Jenny, C. and G. Stampfli, 2000. Permian paleogeography of the tethyan realm. Permophiles, 37: 24-33.

Kidder, D.L. and T.R. Worsley, 2004. Causes and consequences of extreme permo-triassic warming to globally equable climate and relation to the permo-triassic extinction and recovery, 203(3-4): 207237.

Kobayashi, F., 2006. Middle permian foraminifers of the Izuru and nabeyama Formations in the Kuzu area, central Japan. Part 2. Schubertellid and ozawainellid fusulinoideans and non-fusulinoidean foraminifers. Paleontological Research, 10: 61-77.

Motiei, H., 1994. Stratigraphy of Zagros: Publ. Geol. Survey of Iran (In Farsi): 536.

Motiei, H., 1995. Petroleum geology of Zagros: Publ. Geol. Survey of Iran (In Farsi): 589. 
Nilforoushan, F., F. Masson, P. Vernant, C. Vigny, J. Martinod, M. Abbassi, H. Nankali, D. Hatzfeld, R. Bayer, F. Tavakoli, A. Ashtiani, E. Doerflinger, M. Daignieres, P. Collard and J. Chery, 2003. GPS network monitors the Arabia-Eurasia collision deformation in Iran. Journal of Geodesy, 77(7-8): $411-422$.

Ricou, L.E., 1971. Le croissant ophiolitique peri-arabe. Une ceinture de nappes mises en place au cretace superieur. Rev. Geogr. Phys. Geol. Dyn., 13(4): 327-350.

Ricou, L.E., J.J. Braud and J.H. Brunn, 1977. The Zagros Mem. Soc. Geol. France, 8: 33-52.

Scott, B., 1981. The Eurasian-Arabian and African continental margin Iran to Greece. J. Geol. Soc., London, 138(6): 719-733.

Setudehnia, A., 1978. Mesozoic sequence in Southwest Iran and adjacent area. J. Petr. Geol, 1(1): 3-42.

Sharland, P.R., R. Archer, D.M. Casey, R.B. Davies, S.H. Hall, A.P. Heward, A.D. Horbury and M.D. Simmon, 2001 . Arabian plate sequence stratigraphy. Manama Bahrain: Oriental Press.

Stocklin, J., 1968. Structural history and tectonics of Iran: A review. Am. Ass. Petr. Geol Bull., 52(7): 12291258.

Szabo, F. and A. Kheradpir, 1978. Permian and triassic stratigraphy, Zagros basin, South-West Iran. J. Petrol. Geol., 1(2): 57-82.

Vachard, D., M. Hauser, R. Martini, L. Zaninetti, A. Matter and T. Peters, 2002. Middle permian foraminiferal assemblages from the batain plain: Their significance to neotethyan paleogeography. Journal of Foraminiferal Research, 32(2): 155-172. 